\title{
EFFECT OF A PHENYLBUTAZONE ANALOG (4-[PHENYLTHIOETHYL]-1,2- DIPHENYL 3,5-PYRAZOLIDINEDIONE) ON URATE CLEARANCE AND OTHER DISCRETE RENAL FUNCTIONS IN GOUTY SUBJECTS. EVALUATION AS URICOSURIC AGENT ${ }^{1}$
}

\author{
BY T. F. YU, BRUCE C. PATON, THEODORE CHENKIN, J. J. BURNS,
} BERNARD B. BRODIE, AND ALEXANDER B. GUTMAN

\author{
(From the Departments of Medicine, The Mount Sinai Hospital, and Columbia University \\ College of Physicians and Surgeons, New York, N. Y.; Research Service, Third (New \\ York University) Medical Division, Goldwater Memorial Hospital, New York, N. Y.; \\ and the Laboratory of Chemical Pharmacology, National Heart Institute, National \\ Institutes of Health, U. S. Public Health Service, Department of Health, \\ Education and Welfare, Bethesda, Md.)
}

(Submitted for publication October 12, 1955; accepted December 5, 1955)

A number of phenylbutazone derivatives and metabolites are under study $(1-4)$ in a joint effort to develop an analog possessing the marked anti-rheumatic properties but not the undesirable side effects of the parent compound. In the course of testing the anti-rheumatic effects in acute gouty arthritis of one of these compounds, G-25671, in which a phenylthioethyl group replaces the butyl side chain of phenylbutazone, marked uricosuric activity was noted $(1,2)$. The interesting properties of this substance suggested further study and a clinical trial in the management of gout.

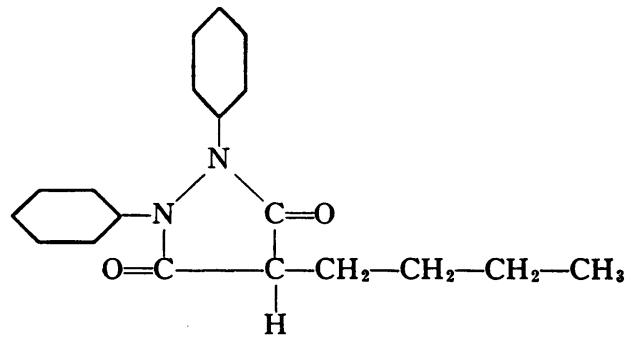

Phenylbutazone

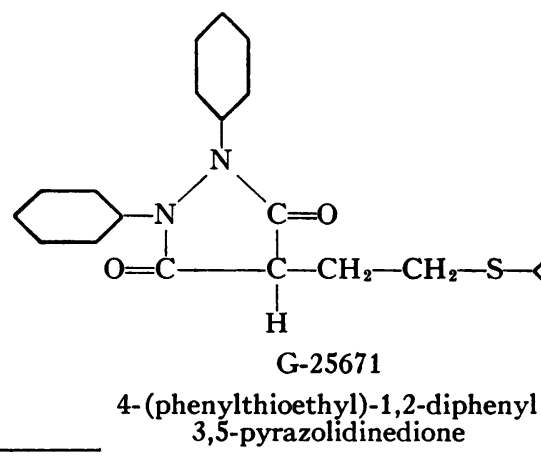

1 This work was supported by a grant-in-aid from the National Institute of Arthritis and Metabolic Diseases, National Institutes of Health.
The present report deals with the effect of G-25671 on the simultaneous renal clearances of inulin, para-aminohippurate, urate, sodium, potassium and chloride. More protracted urate and electrolyte balance studies are included. Our clinical experience with G-25671 in gouty subjects also is briefly summarized.

\section{METHODS}

Renal clearance studies were carried out in 12 gouty subjects, all males 33 to 62 years of age, and in the intercritical phase of the disorder. These subjects had been maintained on a low purine, low fat, restricted protein (60 to $75 \mathrm{gm}$. per day) diet and were in the postabsorptive state at the time of study. Standard clearance techniques (5) were employed, with slight modifications described elsewhere (6).

To ensure adequate urine flow throughout the experiments, liberal quantities of water were administered orally. Urine and blood collections were initiated in three premedication control periods, each of 20 to 30 minutes duration. Then G-25671 was injected intravenously, the rate of injection being varied according to the design of the experiment, and appropriate urine and blood collections were made.

In 7 subjects the total drug dosage, 0.90 to $1.54 \mathrm{gm}$. of the sodium salt (16 mg. per $\mathrm{Kg}$. body weight) dissolved in 100 to $150 \mathrm{ml}$. isotonic saline solution, was delivered within a period of approximately 20 minutes to attain high blood levels of G-25671 rapidly. Injection of the drug was then discontinued and 4 to 6 urine collections were obtained, each comprising a period of 20 to $30 \mathrm{~min}$ utes. Three blood samples were procured during these collection periods. The respective plasma concentrations of inulin, $\mathrm{PAH}$, urate, $\mathrm{Na}, \mathrm{K}$ and $\mathrm{Cl}$ were obtained by plotting the concentrations semilogarithmically against time and by extrapolating back to 2.5 minutes (approximate urine delay time) from the mid-time of each urine collection period. In three of these subjects, A. R., M. C., and L. W., parallel clearance studies with phenylbutazone, 
as the sodium salt, were made. In Cases A. R. and L. W. the effects of injection of $100 \mathrm{ml}$. saline solution alone also were determined.

Five experiments were designed to study the effects of slowly rising drug levels to determine the order of effects on specific renal clearances. In Cases J. S. and L. L., G-25671 as the sodium salt was dissolved in 5 per cent glucose in water to make a 0.14 per cent solution of the drug which was then delivered by sustained intravenous injection. The initial rate of infusion was $1 \mathrm{ml}$. per minute; this was increased by an increment of approximately $1 \mathrm{ml}$. per minute at the beginning of each 20-minute urine collection period to make a total drug dosage of $0.80 \mathrm{gm}$. for Case J. S. and $0.86 \mathrm{gm}$. for Case L. L. Seven such collections were made in each experiment. Blood samples were procured at the mid-point of each clearance period. Parallel experiments were carried out in Cases N. P., J. B., and L. O., in which phenylbutazone as the sodium salt dissolved in 5 per cent glucose in water to make a 0.14 per cent solution of the drug, was delivered by slow infusion.

To obtain information as to the more protracted effects of G-25671, particularly on the renal excretion of sodium, potassium, chloride and inorganic phosphate, two gouty subjects were hospitalized for two weeks during which they were maintained on constant weighed diets

TABLE I

Effect of rapid infusion of $G-25671$ (in isotonic saline solution) on renal clearances of inulin, $P A H$ and urateThree analogous experiments with phenylbutazone are included*

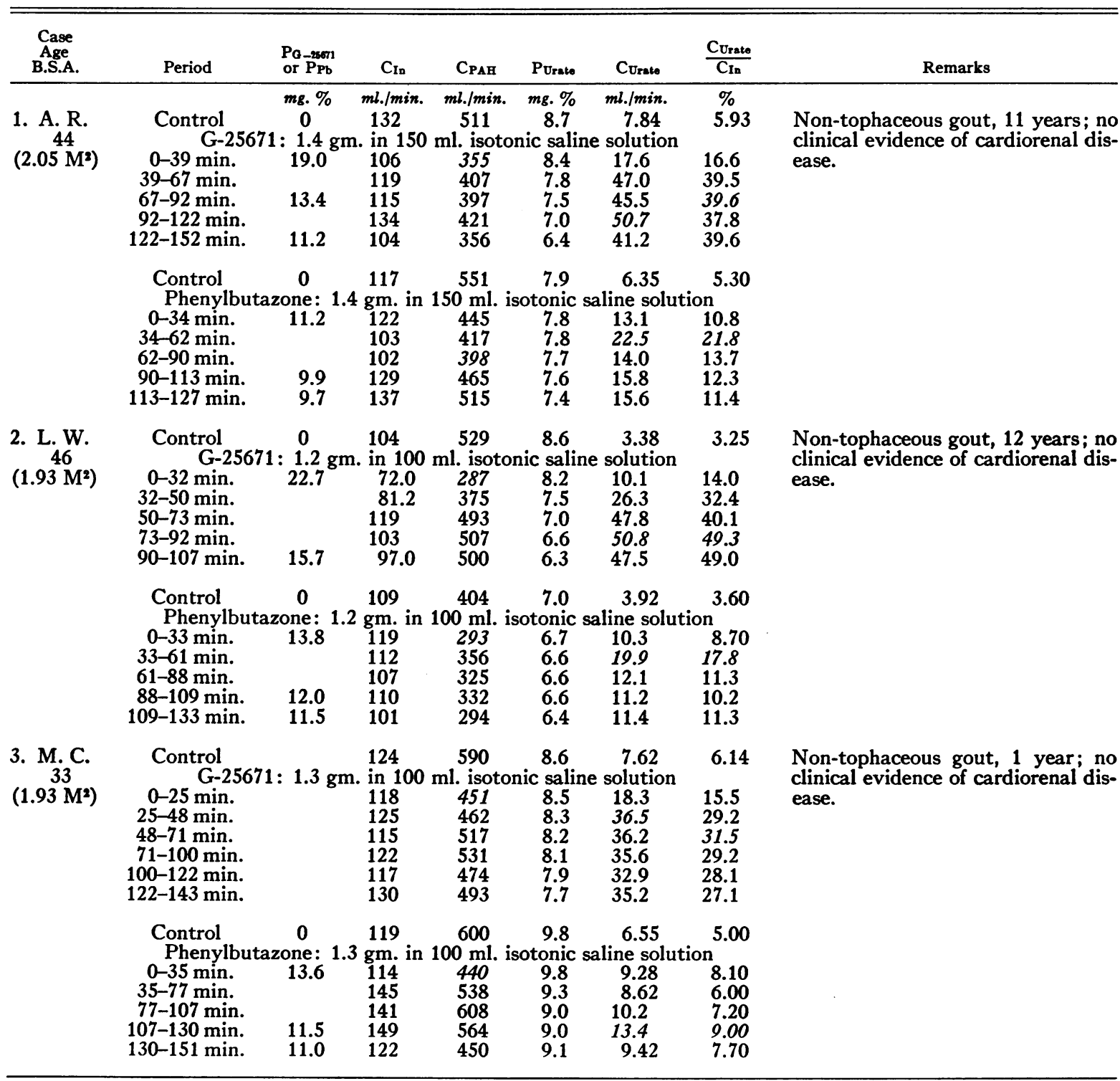


TABLE I-Continued

\begin{tabular}{|c|c|c|c|c|c|c|c|c|}
\hline $\begin{array}{c}\text { Case } \\
\text { Age } \\
\text { B.S.A. }\end{array}$ & Period & $P G_{-25073}$ & $C_{I n}$ & $\mathrm{C}_{\mathrm{PA}}$ & PUrato & CUrato & $\frac{\text { CUrate }}{C_{\text {In }}}$ & Remarks \\
\hline $\begin{array}{c}\text { 4. M. M. } \\
45 \\
\left(1.68 \mathrm{M}^{2}\right)\end{array}$ & $\begin{array}{c}\text { Control } \\
\text { G-25671 } \\
\text { 0-34 min. } \\
\text { 34-54 min. } \\
54-79 \text { min. } \\
79-104 \text { min. } \\
\text { 104-130 min. } \\
130-152 \text { min. }\end{array}$ & $\begin{array}{l}m g . \% \\
0 \\
: 0.95 \mathrm{gn} \\
12.3 \\
10.7 \\
8.4\end{array}$ & $\begin{array}{c}\text { ml./min. } \\
92.4 \\
\text { n. in } 100 \\
93.4 \\
96.0 \\
99.0 \\
104 \\
96.3 \\
92.0\end{array}$ & $\begin{array}{c}\text { ml./min. } \\
416 \\
\text { ml. isoto } \\
334 \\
337 \\
343 \\
337 \\
275 \\
223\end{array}$ & $\begin{array}{c}\text { mg. \% } \\
9.9 \\
\text { nic saline } \\
9.6 \\
9.3 \\
9.0 \\
8.6 \\
8.4 \\
8.3\end{array}$ & $\begin{array}{c}\text { ml. } / \min . \\
4.88 \\
\text { e solution } \\
11.5 \\
28.8 \\
29.6 \\
32.9 \\
22.1 \\
25.2\end{array}$ & $\begin{array}{c}\% \\
5.28 \\
12.3 \\
30.0 \\
29.9 \\
31.7 \\
23.0 \\
27.4\end{array}$ & $\begin{array}{l}\text { Tophaceous gout, } 17 \text { years; no clin- } \\
\text { ical evidence of cardiorenal disease. }\end{array}$ \\
\hline $\begin{array}{l}\text { 5. S. S. } \\
38 \\
\left(1.66 \mathrm{M}^{2}\right)\end{array}$ & $\begin{array}{l}\text { Control } \\
\text { G-25671 } \\
\text { 0-35 min. } \\
\text { 35-59 min. } \\
59-90 \text { min. } \\
90-120 \text { min. }\end{array}$ & $\begin{array}{l}0 \\
1.0 \mathrm{gm} \\
16.7 \\
12.0\end{array}$ & $\begin{array}{c}86.0 \\
\text { in } 100 \\
90.2 \\
88.4 \\
78.9 \\
82.0\end{array}$ & $\begin{array}{l}453 \\
\text { ml. isoto } \\
424 \\
413 \\
429 \\
473\end{array}$ & $\begin{array}{c}9.7 \\
\text { nic saline } \\
9.0 \\
8.4 \\
8.2 \\
7.9\end{array}$ & $\begin{array}{c}6.14 \\
\text { e solution } \\
4.90 \\
8.60 \\
14.3 \\
17.8\end{array}$ & $\begin{array}{l}7.13 \\
\\
5.43 \\
9.73 \\
18.1 \\
21.7\end{array}$ & $\begin{array}{l}\text { Non-tophaceous atypical gout; no } \\
\text { clinical evidence of cardiorenal dis- } \\
\text { ease. }\end{array}$ \\
\hline $\begin{array}{l}\text { 6. H. G. } \\
44 \\
\left(2.08 \mathrm{M}^{2}\right)\end{array}$ & $\begin{array}{c}\text { Control } \\
\text { G-25671 } \\
\text { 0-43 min. } \\
\text { 43-75 min. } \\
75-100 \mathrm{~min} . \\
100-123 \mathrm{~min} . \\
123-153 \mathrm{~min} .\end{array}$ & $\begin{array}{l}0 \\
19.5 \\
19.1\end{array}$ & $\begin{array}{c}83.7 \\
\text { in } 150 \\
83.6 \\
75.2 \\
74.8 \\
72.9 \\
68.0\end{array}$ & $\begin{array}{c}290 \\
\text { ml. isoto } \\
165 \\
183 \\
183 \\
362 \\
333\end{array}$ & $\begin{array}{c}11.5 \\
\text { nic saline } \\
11.1 \\
10.8 \\
10.5 \\
10.2 \\
10.2\end{array}$ & $\begin{array}{c}6.68 \\
\text { e solution } \\
13.8 \\
9.40 \\
10.3 \\
10.8 \\
11.0\end{array}$ & $\begin{array}{l}7.97 \\
16.5 \\
12.5 \\
13.8 \\
14.8 \\
16.2\end{array}$ & $\begin{array}{l}\text { Tophaceous gout, } 11 \text { years; post- } \\
\text { scarlatina nephritis for more than } \\
20 \text { years; albuminuria and cylin-- } \\
\text { druria, serum NPN } 34 \text { mg. } \% \text {, PSP } \\
\text { excretion } 50 \% \text { in } 2 \text { hours. }\end{array}$ \\
\hline $\begin{array}{l}\text { 7. I. K. } \\
62 \\
\left(1.65 \mathrm{M}^{2}\right)\end{array}$ & $\begin{array}{l}\text { Control } \\
\text { G-25671 } \\
0-37 \text { min. } \\
37-62 \text { min. } \\
62-88 \text { min. } \\
88-115 \text { min. }\end{array}$ & $1: 0.9 \mathrm{gr}$ & $\begin{array}{c}64.9 \\
\text { in } 100 \\
64.3 \\
66.7 \\
80.0 \\
79.4\end{array}$ & $\begin{array}{l}202 \\
\text { ml. isoto } \\
147 \\
156 \\
198 \\
208\end{array}$ & $\begin{array}{l}8.7 \\
\text { nic saline } \\
8.4 \\
8.2 \\
8.2 \\
8.2\end{array}$ & $\begin{array}{l}4.76 \\
\text { e solution } \\
9.63 \\
11.5 \\
15.5 \\
18.7\end{array}$ & $\begin{array}{l}7.34 \\
15.0 \\
17.3 \\
19.3 \\
23.6\end{array}$ & $\begin{array}{l}\text { Non-tophaceous gout } 32 \text { years; } \\
\text { nephrosclerosis; albuminuria and } \\
\text { cylindruria, serum NPN } 60 \mathrm{mg} . \% \text {, } \\
\text { PSP excretion } 50 \% \text { in } 2 \text { hours; post- } \\
\text { gastrectomy refractory anemia, } 15 \\
\text { years. }\end{array}$ \\
\hline
\end{tabular}

* Figures italicized indicate maximal changes.

and controlled salt and water intake. The daily caloric intake for subject O. G. was 1600 (protein, $60 \mathrm{gm}$. per day), with $2.5 \mathrm{gm}$. of sodium chloride added; subject L. W. received 1800 calories per day (protein, $60 \mathrm{gm}$. per day) with $3.5 \mathrm{gm}$. sodium chloride added. On the seventh day of hospitalization, G-25671 administration was begun: $O$. G. received $1.2 \mathrm{gm}$. intravenously every day for four consecutive days, delivered in three divided doses of $0.4 \mathrm{gm}$. (in $100 \mathrm{ml}$. 5 per cent glucose in distilled water) at 9:00 A.M., 3:00 P.M., and 9:00 P.M.; L. W. received $1.6 \mathrm{gm}$. intravenously for four consecutive days, similarly delivered daily in three divided doses of $0.4 \mathrm{gm}$. (9:00 A.M.), 0.4 gm. (3:00 P.M.) and 0.8 gm. (9:00 P.M.). Blood samples were secured just prior to each infusion. Urine collections, obtained by spontaneous voidings, were spaced to comprise the periods from 9:00 A.M. to 3:00 P.M., then to 9:00 P.M., and overnight to 9:00 A.M. The urine was collected over the three days immediately preceding medication, the four days of G-25671 administration, and three days thereafter. The body weight was recorded each morning. Parallel studies with phenylbutazone had previously been made in these two subjects (7).

The analytical methods for the determination of urate, inulin, creatinine, para-aminohippurate, sodium, potassium, chloride, and inorganic phosphate were the same as previously employed (6). Plasma concentrations of G-25671 were measured by the method previously de- scribed (8) for phenylbutazone except that 3 per cent isoamyl alcohol was added to the petroleum ether used for extraction of the drug and the optical densities were measured at $255 \mathrm{~m} \mu$.

\section{RESULTS}

\section{Plasma levels of G-25671 after intravenous in- jection}

The plasma levels of G-25671 obtained when the total dosage of drug (16 mg. per $\mathrm{Kg}$. body weight) was delivered in one rapid injection varied from 22.7 to $12.3 \mathrm{mg}$. per cent at the mid-point of the first post-medication collection period (Table I). In every instance the plasma concentration of the drug declined in the course of the experiment, the final concentrations ranging from 15.7 to $8.4 \mathrm{mg}$. per cent. This is in contrast to the very slow disappearance of phenylbutazone from the plasma (7).

In two experiments involving sustained infusion of the drug at increasing rates (Table II), the plasma concentration of G-25671 was slowly 
increased from initial trace levels to 9.5 and 5.4 mg. per cent, respectively, in Cases J. S. and L. L. Effects of G-25671 on $C_{I n}$ and $C_{P A H}$

In Cases A. R., L. W., and M. C., the values for $C_{\text {In }}$ and $C_{P \Delta H}$ prior to injection of $G-25671$ were within the normal range (Table I). The remaining six subjects were found to have significant reductions in glomerular filtration rate and/or renal plasma flow (Tables I and II), as commonly observed in older patients with a long history of overt gout. Cases J. S. and I. K. exhibited the most marked impairment of renal hemodynamics $\left(C_{\text {In }} 54.4\right.$ and $64.9 \mathrm{ml}$. per min., $\mathrm{C}_{\mathrm{PAB}} 242$ and $202 \mathrm{ml}$. per min., respectively).

Infusion of G-25671 in the dosage employed did not significantly affect the glomerular filtration rate in five subjects (Tables I and II). In three instances $\mathrm{C}_{\text {In }}$ was appreciably although transitorily depressed, to a maximum of -30 per cent in

TABLE II

Effect of slow, sustained infusion of G-25671 and of phenylbutazone (in glucose solution) on renal clearances of inulin, urate, sodium, potassium and chloride

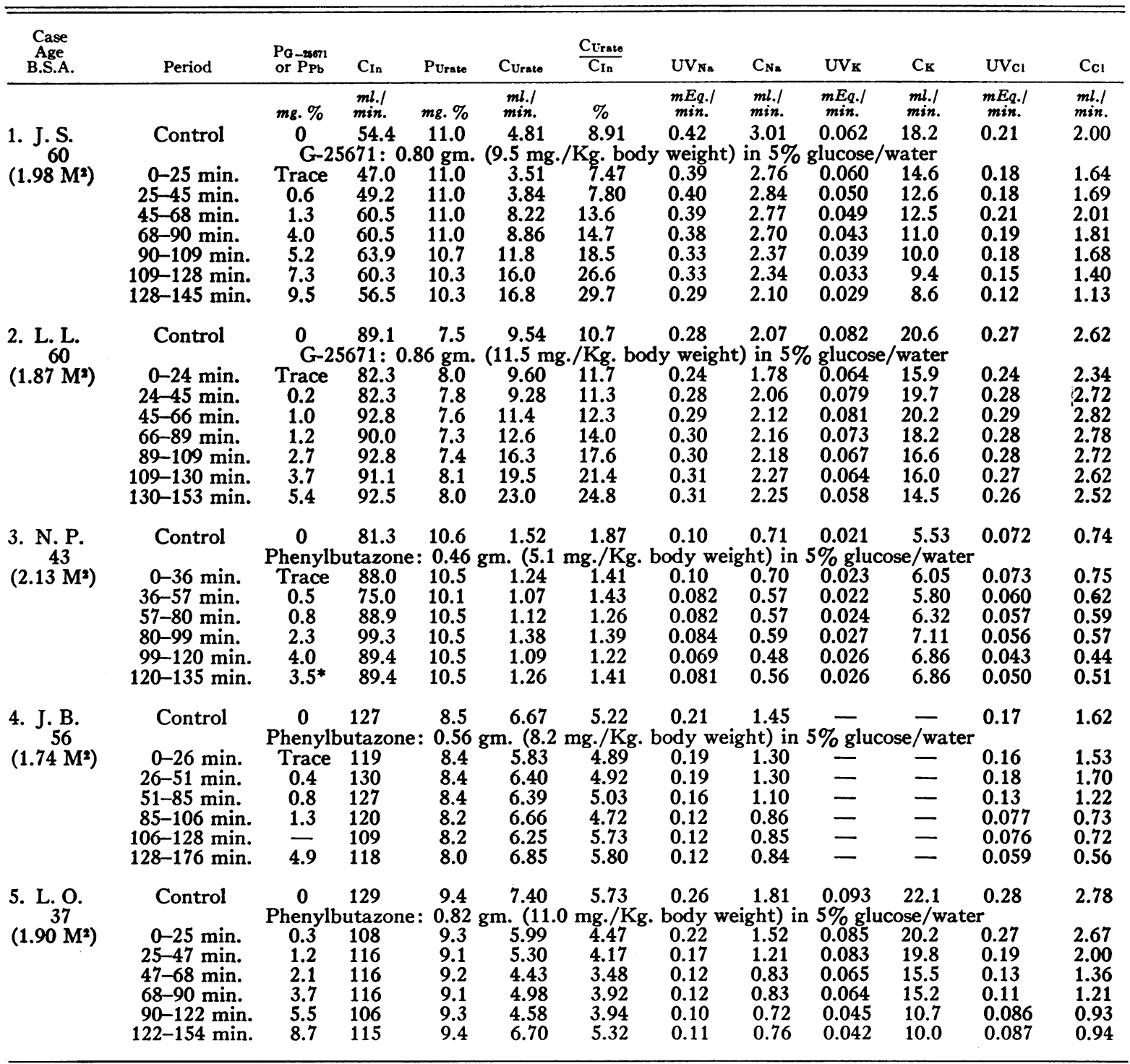

* Phenylbutazone stopped after 120 minutes. 


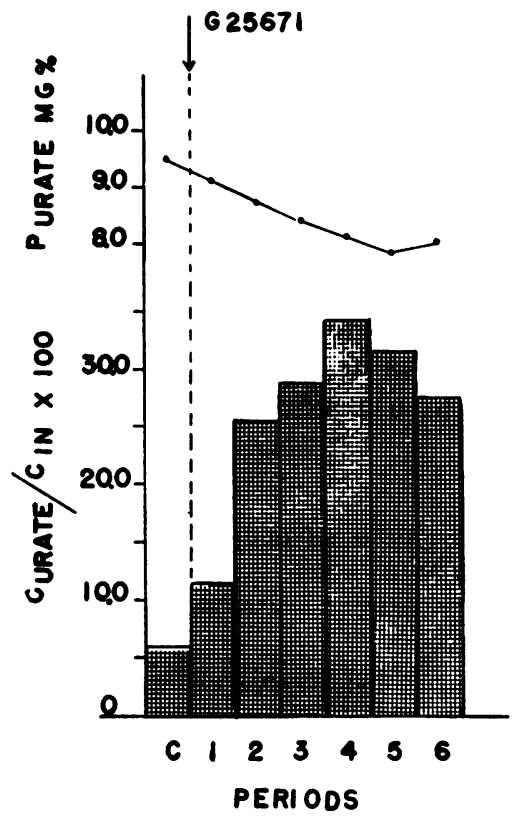

Fig. 1. EFfect of Rapid Intravenous Infusion of G-25671, in 16 Mg. Per Kg. Body Weight Dosage, on Urate Clearance and Serum Urate Levels

The bars represent the means of seven urate/inulin clearance ratio determinations before injection $(C)$ and in six post-injection collection periods. The line above represents the concomitant mean serum urate response in these seven experiments.

Case L. W., -20 per cent in Cases A. R. and H. G. A pyrogenic reaction to the infusion in Case I. K. was associated with a transient rise in $\mathrm{C}_{\text {In }}$. The overall change in $\mathrm{C}_{\text {In }}$ following G-25671 infusion was negligible in most instances. Phenylbutazone in comparable dosage likewise usually has little or no effect on the glomerular filtration rate but may depress $\mathrm{C}_{\text {In }}$ in some instances, more consistently when larger doses are employed (7).

$\mathrm{C}_{\mathbf{P A H}}$ was rapidly and consistently depressed by G-25671 (Table I), the mean control value of $402 \mathrm{ml}$. per min. falling to a mean minimum of 284 $\mathrm{ml}$. per min., an average decline approximating 30 per cent. This effect is presumed to be due to decreased renal extraction of $\mathrm{PAH}$ rather than to reduction in renal blood flow, since phenylbutazone (7) markedly depresses $T \mathrm{~m}_{\mathrm{PAH}}$. Both drugs significantly suppress the rate of phenolsulfonphthalein excretion (1), another indication of depression of tubular excretory mechanisms.

\section{Effect of $G-25671$ on urate clearance}

A marked increase in urate clearance occurred in every instance upon exhibition of the drug and was invariably apparent in the first collection period (Table $\mathrm{I}$ ). The mean $\mathrm{C}_{\text {urate }} / \mathrm{C}_{\text {In }}$ ratio rose from a pre-medication value of 6.15 per cent to a five-fold peak of 30.6 per cent. This effect was more pronounced in the subjects with normal renal hemodynamics (Cases A. R., L. W., and $M$. C.) whose $C_{\text {urate }} / C_{\text {In }}$ ratio rose from a mean of 5.11 per cent to a mean peak of 40.1 per cent but was readily demonstrable also in those with depressed $\mathrm{C}_{\mathrm{In}}$ and $\mathrm{C}_{\mathbf{P A H}}$, whose mean pre-medication $\mathrm{C}_{\text {urate }} / \mathrm{C}_{\text {In }}$ ratio of 6.93 per cent increased to 23.4 per cent (Table I). The uricosuria induced by injection of G-25671 was associated invariably and roughly proportionately with a progressive decline in serum urate concentration, from a mean initial level of $9.3 \mathrm{mg}$. per cent to a mean minimum of $8.0 \mathrm{mg}$. per cent at the end of the period of observation (Figure 1). The fall in serum urate in individual patients ranged from 2.3 to $0.5 \mathrm{mg}$. per cent.

The data in Table II indicate that G-25671 begins to exert its uricosuric effect at low plasma concentrations of the drug, approximating $1 \mathrm{mg}$. per cent, and that this action is progressively enhanced as the drug levels rise.

The uricosuric action of G-25671 is attributable to suppression of tubular reabsorption of urate. The percentage of filtered urate which was reabsorbed (i.e., filtered - UV/filtered) was calculated to fall, under the influence of the drug, from a mean pre-medication value of 93.9 per cent to a mean minimum of 70.2 per cent (in Case L. W., to as low as 50.8 per cent). As already implied, the quantity of urate filtered at the glomerulus was not significantly altered by the drug; no significant change in the proportion of plasma urate which is filtrable need be assumed (9); and the rapidity of the uricosuric action precluded any appreciable urate moiety due to augmented metabolic degradation of nucleic acids.

\section{Effect of G-25671 on clearance and excretion $(U V)$ of sodium, potassium and chloride}

The experiments summarized in Table $I$ included simultaneous determinations of $\mathrm{C}_{\mathrm{Na}}, \mathrm{C}_{\mathrm{K}}$ and $\mathrm{C}_{\mathrm{Cl}}$. The results (data not included in Table 
I) indicated an increase in sodium clearance in four of the seven subjects studied, no significant change in two, and a decrease in one; these alterations did not correlate with any changes in glomerular filtration rate. $\mathrm{C}_{\mathrm{Cl}}$ paralleled $\mathrm{C}_{\mathrm{Na}}$ throughout. $\mathrm{C}_{\mathrm{K}} / \mathrm{C}_{\mathrm{In}}$ ratios were not significantly altered.

The increased sodium and chloride excretion noted in four subjects does not, under the conditions of these experiments, demonstrate that G-25671 may elicit sodium chloride diuresis since 14.2 to $24.0 \mathrm{mEq}$. of sodium, as sodium chloride solution and sodium salt of G-25671, were infused concomitantly with the drug. Calculation of the net electrolyte balance in fact revealed some retention of sodium, from 12.1 to $26.7 \mathrm{mEq}$. over the approximately 2-hour period of the experiment, in every patient except $I$. $K$. who developed a pyrogenic reaction. In Cases $\mathrm{A}$. $\mathrm{R}$. and $\mathrm{L}$. W. (who received equivalent infusions of sodium chloride with and without the drug) 26.7 and 6.0 $\mathrm{mEq}$. sodium, respectively, were retained when the drug, in saline solution, was infused, and 14.7 and $-1.6 \mathrm{mEq}$. sodium when sodium chloride alone was injected.

In two clearance experiments summarized in Table II, G-25671 was infused in a 5 per cent solution of glucose in water. Case J. S. shows retention of sodium chloride, Case $\mathrm{L}$. L d does not. In both instances $U V_{K}$ and $C_{\mathbf{K}}$ fell significantly; this result, which was not obtained in any experiments involving saline solution as a vehicle for G-25671, is attributed to the infusion of glucose and the utilization of potassium for glycogen formation.

\section{Balance studies: G-25671 given by repeated intra- venous injection}

The observations made by the use of clearance techniques were supplemented by more protracted urate and electrolyte balance studies. In two such experiments G-25671 was administered intravenously in daily doses of $1.2 \mathrm{gm}$. (Case O.G.) and $1.6 \mathrm{gm}$. (Case L. W.), given in three divided doses, over a four-day period (Figure 2). These doses brought the plasma drug level in Case O. G. to $6.0 \mathrm{mg}$. per cent after $24 \mathrm{hrs}$. and to $11.8 \mathrm{mg}$. per cent on the fourth day of medication. In Case
L. W. the plasma drug levels were $4.0 \mathrm{mg}$. per cent and $9.7 \mathrm{mg}$. per cent, respectively.

Patient O. G., whose mean urinary urate excretion was $408 \mathrm{mg}$. per $24 \mathrm{hrs}$. in the 3-day control period, increased his mean daily output to 626 $\mathrm{mg}$. per $24 \mathrm{hrs}$. during the period of drug injection, a total excess urinary urate excretion of $872 \mathrm{mg}$. for the 4-day period of drug administration. This was associated with a sharp fall in serum urate, from $9.7 \mathrm{mg}$. per cent to $2.6 \mathrm{mg}$. per cent. Upon discontinuance of medication the urinary urate excretion fell below pre-medication levels to a mean of $270 \mathrm{mg}$. per $24 \mathrm{hrs}$. ; this period of urate retention was associated with a slow rise in serum urate level to $6.7 \mathrm{mg}$. per cent after 3 days. $\mathrm{Pa}$ tient L. W. excreted a mean of $454 \mathrm{mg}$. urate per $24 \mathrm{hrs}$. in the control period. On the first day of drug injection the urinary urate output rose to

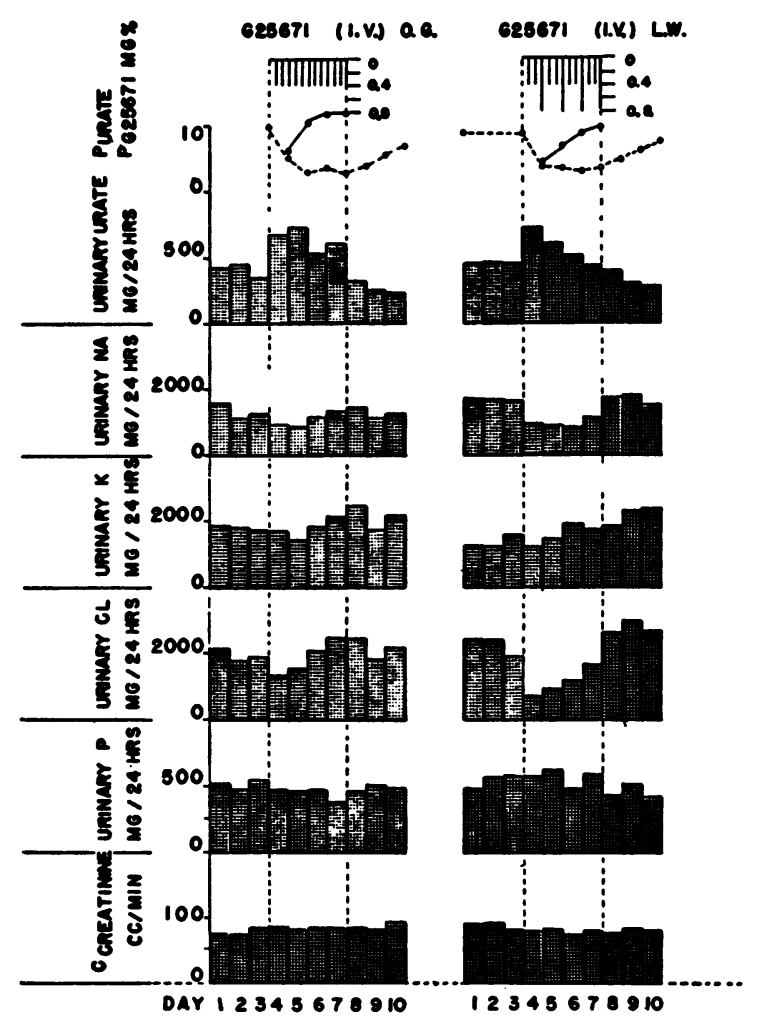

Fig. 2. Cases O. G. and L. W. Urinary Excretion per 24 hrs. of Urate, Sodium, Potassium, Chloride and Inorganic Phosphate Before, During, and After Daily Intravenous InJection of G-25671 in the DosAGE INDICATED AT THE TOP

The effect on "endogenous" creatinine clearance is indicated at the bottom of the figure, the serum urate levels (hollow dots) and serum G-25671 (solid dots) above. 
TABLE III

Effect of G-25671 on serum and urinary urate in five gouty subjects

(Dosage $1.0 \mathrm{gm}$. per day)

\begin{tabular}{|c|c|c|c|c|c|c|c|c|c|c|c|}
\hline \multirow[b]{2}{*}{ Case } & \multirow[b]{2}{*}{ Uric acid } & \multirow{2}{*}{$\begin{array}{c}\text { Pre- } \\
\text { medication }\end{array}$} & \multicolumn{7}{|c|}{ Day of medication } & \multicolumn{2}{|c|}{$\begin{array}{l}\text { Day of post- } \\
\text { medication }\end{array}$} \\
\hline & & & 1 & 2 & 3 & 4 & 5 & 6 & 7 & 1 & 2 \\
\hline 1. J. Z. & $\begin{array}{l}\text { Serum (mg./100 ml.) } \\
\text { Urine (mg./24 hrs.) }\end{array}$ & $\begin{array}{r}9.1 \\
604\end{array}$ & $\begin{array}{r}6.6 \\
1,250\end{array}$ & $\begin{array}{r}4.3 \\
1,337\end{array}$ & $\begin{array}{r}3.0 \\
1,095\end{array}$ & $\begin{array}{l}3.0 \\
818\end{array}$ & 717 & $\begin{array}{l}3.7 \\
785\end{array}$ & $\begin{array}{r}3.4 \\
805\end{array}$ & $\begin{array}{r}5.0 \\
560\end{array}$ & $\begin{array}{r}5.7 \\
393\end{array}$ \\
\hline 2. R. C. & $\begin{array}{l}\text { Serum } \\
\text { Urine }\end{array}$ & $\begin{array}{r}11.3 \\
852\end{array}$ & $\begin{array}{r}10.0 \\
975\end{array}$ & $\begin{array}{r}7.8 \\
1,597\end{array}$ & $\begin{array}{r}7.9 \\
1,476\end{array}$ & $\begin{array}{r}7.8 \\
1,133\end{array}$ & $\begin{array}{r}7.1 \\
1,158\end{array}$ & 1,409 & $\begin{array}{r}7.3 \\
1,450\end{array}$ & $\begin{array}{r}9.8 \\
848\end{array}$ & $\begin{array}{r}12.0 \\
654\end{array}$ \\
\hline 3. A. K. & $\begin{array}{l}\text { Serum } \\
\text { Urine }\end{array}$ & $\begin{array}{r}12.6 \\
493\end{array}$ & $\begin{array}{r}10.6 \\
911\end{array}$ & $\begin{array}{r}5.8 \\
1,268\end{array}$ & $\begin{array}{r}5.4 \\
910\end{array}$ & & $\begin{array}{r}5.6 \\
922\end{array}$ & & & $\begin{array}{r}7.6 \\
576\end{array}$ & $\begin{array}{r}11.4 \\
512\end{array}$ \\
\hline 4. R. E. & $\begin{array}{l}\text { Serum } \\
\text { Urine }\end{array}$ & $\begin{array}{r}11.1 \\
424\end{array}$ & $\begin{array}{r}9.6 \\
606\end{array}$ & $\begin{array}{r}6.5 \\
866\end{array}$ & $\begin{array}{r}7.5 \\
702\end{array}$ & $\begin{array}{r}5.4 \\
531\end{array}$ & & & & $\begin{array}{l}6.2 \\
316\end{array}$ & $\begin{array}{r}7.1 \\
487\end{array}$ \\
\hline 5. L. C. & $\begin{array}{l}\text { Serum } \\
\text { Urine }\end{array}$ & $\begin{array}{r}9.2 \\
671\end{array}$ & $\begin{array}{r}7.4 \\
972\end{array}$ & $\begin{array}{r}5.6 \\
938\end{array}$ & $\begin{array}{r}4.8 \\
938\end{array}$ & & & & & $\begin{array}{r}5.8 \\
605\end{array}$ & $\begin{array}{r}7.1 \\
487\end{array}$ \\
\hline
\end{tabular}

$736 \mathrm{mg}$. per $24 \mathrm{hrs}$., then declined to $596 \mathrm{mg}$. per $24 \mathrm{hrs}$. and thereafter to control levels-a temporary uricosuria often encountered when the quantity of mobilizable urate deposit is small and readily depleted, as in this instance. The serum urate level, initially $8.7 \mathrm{mg}$. per cent, fell to approximately $3.0 \mathrm{mg}$. per cent and remained there throughout the period of drug administration. This is an indication of continued suppression of tubular reabsorption of urate, despite the return of urinary urate excretion levels to pre-medication values. Discontinuance of the drug was followed by urinary urate retention and slow rise of the serum urate level.

In Case O. G. the mean control level of urinary sodium excretion, $1.32 \mathrm{gm}$. per $24 \mathrm{hrs}$., was reduced to a mean of $0.95 \mathrm{gm}$. per $24 \mathrm{hrs}$. for the first two days of drug administration, then reverted to the control figures; the urinary chloride excretion closely paralleled these changes. Case L. W., whose sodium chloride intake and drug dosage were greater than in Case O. G., showed more marked and sustained sodium chloride retention. The mean urinary sodium excretion in the control period, $1.69 \mathrm{gm}$. per $24 \mathrm{hrs}$., fell to a mean of $0.96 \mathrm{gm}$. per $24 \mathrm{hrs}$. during the 4-day period of drug administration. The urinary chloride excretion fell concomitantly to a mean of approximately 50 per cent of the mean control period levels. The urinary excretion of potassium, inorganic phosphate and creatinine was not significantly altered by G-25671.

The serum levels of sodium, potassium, chloride and inorganic phosphate remained essentially unchanged throughout the experiments. There was no significant decrease in the hematocrit in either patient although Case L. W. gained two pounds in weight.

\section{Effect of oral administration of G-25671 on uri- nary urate excretion and serum urate levels}

Table III records the day-by-day uricosuric response to daily doses of $1.0 \mathrm{gm}$. G-25671, given in five divided doses of 0.2 gm., in 5 gouty subjects maintained on a constant diet low in purines and fats, and containing 60 to $80 \mathrm{gm}$. protein per day. The mean increase in urinary urate excretion with this dosage was $\mathbf{5 5}$ per cent at the end of the first 24-hours of medication, reached a peak of 97 per cent after 48 hours, and continued to be augmented so long as the drug was administered. There was a concomitant sharp and sustained fall in serum urate. Cessation of medication was invariably followed by a period of urate retention.

Data on the response of the serum urate level are available in 13 gouty subjects, free of significant impairment of renal function, after oral administration of G-25671 in $1.0 \mathrm{gm}$. daily dosage. The mean pre-medication figure of $9.6 \mathrm{mg}$. per cent was reduced to a mean minimum of 4.7 mg. per cent.

A special study was made of the uricosuric response to G-25671 of gouty subjects with marked renal damage, since it is this category 
which is most apt to be refractory to uricosuric agents, even in doses larger than ordinarily employed. Observations were made in five such patients after $1.0-\mathrm{gm}$. daily dosage and, in all but one, subsequently after 2.0 -gm. daily dosage. In Case J. D., the initial urinary urate excretion of $656 \mathrm{mg}$. per $24 \mathrm{hrs}$. and serum urate level of 10.8 mg. per cent changed, with 1.2 gm. G-25671 daily, to $834 \mathrm{mg}$. per $24 \mathrm{hrs}$. and $7.7 \mathrm{mg}$. per cent, respectively, and then to $1140 \mathrm{mg}$. per $24 \mathrm{hrs}$. and $5.9 \mathrm{mg}$. per cent with 2.0 -gm. daily dosage. In Case S. R., the respective figures were $968 \mathrm{mg}$. per $24 \mathrm{hrs}$. and $14.7 \mathrm{mg}$. per cent before medication; $1332 \mathrm{mg}$. per $24 \mathrm{hrs}$. and $7.2 \mathrm{mg}$. per cent with $1.2 \mathrm{gm}$. drug daily; $1145 \mathrm{mg}$. per $24 \mathrm{hrs}$. and $5.2 \mathrm{mg}$. per cent with $2.0 \mathrm{gm}$. drug daily. In Case S. T., the initial serum urate level of 10.6 mg. per cent fell to $9.7 \mathrm{mg}$. per cent on 1.2-gm. daily dosage and to $7.6 \mathrm{mg}$. per cent on 2.0 -gm. daily dosage. In Case L. M., the response was altogether unsatisfactory: With $1.2 \mathrm{gm}$. G-25671 daily both urinary urate excretion and serum urate level were essentially unchanged from the initial figures of $805 \mathrm{mg}$. per $24 \mathrm{hrs}$., and $12.6 \mathrm{mg}$. per cent, respectively, and an attempt to increase the dosage had to be discontinued because of the appearance of a drug rash. Case G. S., who gave a typical history of chronic glomerulonephritis (with serum NPN $91 \mathrm{mg}$. per cent, PSP excretion 20 per cent in 2 hours) as well as gout, also responded unsatisfactorily. The pre-medication urinary urate excretion of $288 \mathrm{mg}$. per $24 \mathrm{hrs}$. was unchanged with 1.2 -gm. daily dosage although the serum urate level fell from 11.1 to $9.4 \mathrm{mg}$. per cent; on 2.0 -gm. daily dosage the urinary urate excretion was $228 \mathrm{mg}$. per $24 \mathrm{hrs}$. and the serum urate $7.7 \mathrm{mg}$. per cent.

\section{Anti-rheumatic action}

Animal screening tests indicate that G-25671 possesses marked anti-inflammatory properties in experimental inflammations. ${ }^{2}$ This action is demonstrable also in man but the effects are distinctly less marked and less consistent than with phenylbutazone (1). Thus of 10 acute gouty attacks treated with $1.0 \mathrm{gm}$. G-25671 daily, only three

2 We are indebted to R. Domenjoz and G. Wilhelmi of Geigy Pharmaceuticals for this information. remitted completely within 24 to 48 hours, two within 72 hours, four improved temporarily but recurred promptly upon discontinuance of the drug, and in one instance the dosage had to be increased to $2.0 \mathrm{gm}$. per day because of inadequate response. All these patients showed the usual prompt and marked uricosuria, with decline in serum urate levels.

These results discouraged further trial of G-25671 in the termination of severe attacks of acute gouty arthritis but suggested that, apart from its uricosuric action, the drug might be useful in the control of pain and stiffness associated with chronic gouty arthritis. Of six such cases studied, four were promptly relieved of pain and stiffness with doses of $1.2 \mathrm{gm}$. daily, two only when the dosage was increased to $2.0 \mathrm{gm}$. daily. One of the patients, who received the drug in $2.0-\mathrm{gm}$. daily dosage continuously for 10 months, shows definite reduction in the size of tophi.

Despite relief of chronic joint symptoms, however, G-25671 in 1.0-gm. or 2.0-gm. daily dosage proved to be ineffective as a prophylactic agent in preventing recurrence of acute gouty arthritis in 4 of 7 patients receiving the drug for protracted periods.

\section{Toxic reactions to $G-25671$}

The drug was administered to 28 gouty subjects in all, 21 for studies of less than one week's duration, 7 continuously and without adverse effects for periods of 3 to 10 months. Three patients developed a rash (one urticarial, one erythematous, 1 purpuric), in every instance within a day or two of initiation of medication; one had reacted similarly to phenylbutazone. One patient developed a renal calculus, another noted "sand" in the urine, a third complained of renal colic. One patient complained of anorexia, one of marked constipation, the only gastro-intestinal complications encountered. The drug did not appear to precipitate acute gouty arthritis when first administered but, as already mentioned, did not prevent recurrence of acute seizures in the course of protracted usage. Careful checks at regular intervals in the 7 patients receiving the drug for 3 to 10 months failed to reveal any indication of bone marrow depression, hepatotoxicity or neurotoxicity. 


\section{DISCUSSION}

The effects of G-25671 on discrete renal functions, as described in the preceding section, differ in significant respects from those observed with equivalent dosages of phenylbutazone, notably in relation to tubular reabsorption of urate and of salt and water. These differences, brought about by substitution of a phenylthioethyl group for the butyl side chain of the parent compound, appear to be quantitative rather than qualitative in nature, as will be made evident in detailed comparisons to follow. Nevertheless they are of such order of magnitude as to impart potential clinical usefulness to G-25671 as a uricosuric drug in the management of gout (1), phenylbutazone not being serviceable for this purpose (7). The data now at hand make possible a provisional assessment of G-25671 as a uricosuric agent.

\section{Comparison of uricosuric effects of phenylbutazone and $G-25671$}

It was found in a prior study (7) of ten gouty subjects that intravenous injection of phenylbutazone in dosages ranging from 12 to $27 \mathrm{mg}$. per $\mathrm{Kg}$. body weight caused a rise in $\mathrm{C}_{\text {urate }} / \mathrm{C}_{\text {In }}$ ratios from a mean control value of 6.04 per cent to a mean peak of 19.5 per cent, an approximately three-fold increase. The data of the present analogous study with G-25671, given intravenously in a dosage of $16 \mathrm{mg}$. per $\mathrm{Kg}$. body, indicate an approximately five-fold mean peak rise in $\mathrm{C}_{\text {arate }} / \mathrm{C}_{\text {In }}$, from a premedication value of 6.15 per cent to 30.6 per cent. Direct comparisons, made in the same patient, more convincingly demonstrate the greater uricosuric efficacy of G-25671 (Table I). In Case A. $R$., the $C_{\text {urate }} / C_{\text {In }}$ ratio rose from 5.9 per cent to a peak of 39.6 per cent with G-25671 whereas with the same dosage of phenylbutazone the rise was from 5.3 per cent to 21.8 per cent; in Case L. W., the respective increases were from 3.3 per cent to 49.3 per cent with G-25671 and from 3.6 per cent to 17.8 per cent with phenylbutazone; in Case M. C., from 6.1 per cent to 31.5 per cent and from 5.0 per cent to 9.0 per cent, respectively. Since these and similar comparisons of the two drugs were made with dosages equivalent on a drug-weight basis, the actual dosage of G-25671 administered was approximately 25 per cent less than that of phenylbutazone when calculated on an equi-molecular basis (molecular weight of phenylbutazone, 298; of G-25671, 384).$^{8}$

There has been some difference of opinion as to whether phenylbutazone, when administered orally, exerts any uricosuric action in the usual dosage, 400 to $800 \mathrm{mg}$. daily. The preponderance of evidence $(7,10,11$ and others) clearly indicates that phenylbutazone increases urinary urate excretion when plasma drug concentrations approximating $10 \mathrm{mg}$. per cent or more are attained, for which regular oral doses of at least $600 \mathrm{mg}$. per day ordinarily are required (10). A decline in serum urate concentration may precede distinct uricosuria but this appears to be largely factitious, usually the result of hemodilution due to marked salt and water retention.

The available data on G-25671 indicate that this drug, when given orally, elicits increases in urinary urate excretion and associated falls in serum urate concentration at least as great as probenecid in equivalent dosage (12). The uricosuric action begins at plasma drug levels approximating $1 \mathrm{mg}$. per cent, and effective blood levels are readily achieved when the drug is given orally in the daily dosage we have ordinarily employed, 1.0 gm. per day. Because of the short biologic halflife of G-25671 (about 3 hours compared to 70 hours for phenylbutazone) (1) maintenance of effective plasma drug levels throughout the day requires distribution in divided doses. We give $0.2 \mathrm{gm}$. every 4 hours from 7:00 A.M. to 11:00 P.M.

\section{Comparison of effects of phenylbutazone and G-25671 on salt and water retention}

It is well known that phenylbutazone may cause marked retention of salt and water; indeed, the

${ }^{3}$ Several additional phenylbutazone analogs, representing other substitutions in the side chain, have been tested in respect to their uricosuric action. G-25903, in which a phenylthiopropyl side chain replaces the phenylthioethyl group of G-25671, has much less uricosuric effect than G-25671 or phenylbutazone; $2 \mathrm{gm}$. per day by mouth elicits only a 25 per cent increase in urinary urate excretion. On the other hand, G-25669 (isopropylthioethyl analog) and G-25921 (p-chlorophenylthioethyl ana$\log$ ) are both very potent uricosuric agents. All three of these compounds undergo rapid biotransformation and have a half-life approximating that of G-25671. 
clinical consequences thereof, in particular expansion of the intravascular fluid compartment, represent a hazard in the use of the drug. In our own experience (7), the urinary excretion of sodium in one patient studied, Case O. G., fell from $0.81 \mathrm{gm}$. per $24 \mathrm{hrs}$. to $0.37 \mathrm{gm}$. per $24 \mathrm{hrs}$. when $0.8 \mathrm{gm}$. phenylbutazone was infused daily; the corresponding figures for urinary chloride excretion were 1.63 and $0.92 \mathrm{gm}$. per $24 \mathrm{hrs}$., respectively. This patient was maintained throughout the experiment on a constant low-sodium diet to which $2.5 \mathrm{gm}$. sodium chloride a day was added. In another instance (7), Case L. W., who also received $0.8 \mathrm{gm}$. phenylbutazone by intravenous injection, the urinary excretion of sodium fell from 2.20 to $1.13 \mathrm{gm}$. per $24 \mathrm{hrs}$., the urinary chloride excretion concomitantly from 3.61 to $1.80 \mathrm{gm}$. per 24 hrs. Case L. W.'s low salt diet was supplemented with $3.5 \mathrm{gm}$. sodium chloride daily. In both instances retention of sodium was associated with a rise in serum sodium levels, in Case O. G. from 141 to $150 \mathrm{mEq}$. per L, in Case L. W. from 145 to $156 \mathrm{mEq}$. per L.

These same patients were subjected to analogous experiments with G-25671 which, as indicated by the data of this study already presented, also causes some retention of sodium chloride (Figure 2 ); in equivalent dosage and plasma drug levels, however, significantly less than does phenylbutazone. Thus the urinary sodium excretion in Case O. G. fell from $1.32 \mathrm{gm}$. per $24 \mathrm{hrs}$. to a mean of $0.95 \mathrm{gm}$. per $24 \mathrm{hrs}$. for the first two days of intravenous injection of $1.2 \mathrm{gm}$. G-25671 daily (50 per cent higher dosage than in the corresponding phenylbutazone experiment) but returned to the control level, 1.25 gm. per 24 hrs., as the drug infusion was continued. The corresponding figures for urinary chloride excretion were closely parallel : $1.94 \mathrm{gm}$. per $24 \mathrm{hrs}$. control level, 1.47 $\mathrm{gm}$. per $24 \mathrm{hrs}$. for the first two days, and $2.28 \mathrm{gm}$. per $24 \mathrm{hrs}$. for the last two days of injection. The constant low sodium diet in this instance was supplemented with $2.5 \mathrm{gm}$. sodium chloride daily, as in the corresponding phenylbutazone experiment. Case L. W. received $1.6 \mathrm{gm}$. G-25671 daily by intravenous injection. At this dosage retention of sodium was about as marked as was obtained with $0.8 \mathrm{gm}$. of phenylbutazone: The premedication uri- nary excretion of sodium, $1.69 \mathrm{gm}$. per $24 \mathrm{hrs}$., fell to a mean of $0.96 \mathrm{gm}$. per $24 \mathrm{hrs}$., the urinary chloride excretion fell from 2.26 to $1.14 \mathrm{gm}$. per $24 \mathrm{hrs}$. The low sodium diet in this instance was supplemented with $3.5 \mathrm{gm}$. sodium chloride, as in the prior phenylbutazone experiment.

Owing to the rapid metabolic degradation of G-25671, the tendency to retain sodium chloride was no longer apparent even on the first day of discontinuance of medication whereas the sodiumretaining effect of phenylbutazone was still in evidence 24 to 72 hours thereafter. G-25671 did not cause any hypernatremia, such as was noted with phenylbutazone, and hemodilution was not significant in ordinary clinical dosage.

Another relevant point in this connection was brought out by slow infusion experiments in which the plasma concentration of phenylbutazone or G-25671 was raised gradually in order to determine the relative drug levels required to effect uricosuria and/or sodium retention (Table II). These experiments demonstrate that plasma phenylbutazone levels of 1 to $2 \mathrm{mg}$. per cent are associated with distinct sodium retention (Table II) whereas no increase in urinary urate excretion occurs until plasma drug concentrations of approximately $10 \mathrm{mg}$. per cent are reached $(7,10)$. On the other hand, G-25671 causes distinct uricosuria at plasma drug concentrations of $1 \mathrm{mg}$. per cent, which appear to be insufficient to elicit significant sodium retention. In Case L. O., the plasma phenylbutazone level was slowly raised to $8.7 \mathrm{mg}$. per cent at which point $\mathrm{UV}_{\mathrm{Na}}$ was decreased 58 per cent and $U V_{\mathrm{Cl}}$ declined 66 per cent, yet $\mathrm{C}_{\text {urate }} / \mathrm{C}_{\text {In }}$ approximated the pre-medication ratio. ${ }^{4}$ Case J. B. exhibited the same phenomenon, although not so markedly, at lower plasma phenylbutazone concentrations. In contrast, $\mathrm{C}_{\text {urate }} / \mathrm{C}_{\text {In }}$ increased 130 per cent at a plasma G-25671 concentration of $5.4 \mathrm{mg}$. per cent in Case L. L., without any decline whatsoever in $U_{\mathrm{Na}}$ or $\mathrm{UV}_{\mathrm{Cl}}$. In Case J. S., $\mathrm{C}_{\text {urate }} / \mathrm{C}_{\mathrm{In}}$ increased 35 per cent at a plasma G-25671 concentration of $1.3 \mathrm{mg}$. per cent at which point $U V_{\mathrm{Na}}$ and $U V_{\mathrm{Ol}}$ were unchanged.

\footnotetext{
4 It will be noted that in this and other instances, very low plasma phenylbutazone and G-25671 levels may be associated with reduction in $\mathrm{C}_{\text {urato }} / \mathrm{C}_{\text {inulin. }}$. The significance of this phenomenon is discussed elsewhere (13).
} 
Comparison of clinical usefulness of phenylbutazone and G-25671 in the management of acute and chronic gouty arthritis

The potent anti-rheumatic properties of phenylbutazone have established a limited but definite place for it in the current management of various arthritic disorders, notably in the short-term treatment of acute gouty arthritis. Our own data in this connection conform to the favorable general experience. Of 103 acute gouty seizures in 61 patients, treatment with $800 \mathrm{mg}$. phenylbutazone a day gave complete remission within 24 to 48 hours in 76 ( 74 per cent) and within two days to one week in 14 (14 per cent). Five patients ( 5 per cent) showed a partial response, three ( 3 per cent) did not respond at all and five ( 5 per cent) improved but this was followed by disturbing side effects of the drug. In contrast to these good results with phenylbutazone, only 30 per cent of 10 acute gouty attacks treated with G-25671 (1 gm. daily) remitted completely within 24 to 48 hours, an experience which does not justify use of this drug for termination of acute gouty arthritis. Our experience with G-25671 in protracted daily usage as a prophylactic agent to prevent recurrence of acute gouty seizures also has been discouraging, certainly less satisfactory than with the daily prophylactic use of small doses of colchicine for the purpose (14).

The experience herein described suggests, however, that G-25671 may have potential clinical usefulness as a uricosuric agent in the prevention and treatment of chronic gouty arthritis; it has potent uricosuric and mild anti-rheumatic properties, and causes negligible retention of sodium and water. Since administration as a uricosuric agent would require daily dosage for months or years, the limiting factor in use of the drug for this purpose would appear to be its hazard of significant toxicity. In our own small experience thus far, this hazard does not appear to be excessive. Of 28 gouty subjects treated with the drug, three developed significant side reactions (drug rash, which disappeared promptly upon discontinuance of medication), three had complications referable to excessive uricosuria (a hazard common to all uricosuric agents which can usually be circumvented), none gave evidence of bone marrow depression, hepatotoxicity or neurotoxicity.
The similarity in chemical structure to phenylbutazone, however, suggests caution in the protracted administration of G-25671, and much more extensive and prolonged experience will be necessary to permit conclusions as to its safety for use in the management of chronic gouty arthritis.

Phenylbutazone has been recommended for protracted daily use in gouty subjects (15) but we consider that the toxic hazards entailed do not justify its employment for this purpose (7).

\section{SUM MARY}

1. G-25671 is a phenylbutazone derivative in which a phenylthioethyl group replaces the butyl side chain. The effects of G-25671 on the simultaneous renal clearances of inulin, para-aminohippurate, urate, sodium, potassium and chloride are reported, and the results compared with those obtained with phenylbutazone.

2. Like phenylbutazone, G-25671 usually does not significantly affect the inulin clearance but may lower it in some instances. Both drugs significantly depress $\mathrm{C}_{\mathbf{P A B}}$, apparently as a result of decreased renal extraction of $\mathrm{PAH}$.

3. In seven rapid infusion experiments, G-25671 caused a mean five-fold increase in $\mathrm{C}_{\text {urate }} / \mathrm{C}_{\text {In }}$, from a mean pre-medication value of 6.15 per cent to a mean peak of 30.6 per cent. This uricosuric effect, which is much more pronounced than that of phenylbutazone, is attributable to suppression of tubular reabsorption of urate.

4. G-25671 causes distinctly less sodium and water retention than phenylbutazone in comparable dosage, and exerts its uricosuric action at low plasma drug levels (approximately $1 \mathrm{mg}$. per cent) which are not associated with any discernible effects on tubular transport of electrolytes. Phenylbutazone, in contrast, causes sodium and water retention at low plasma drug levels and uricosuria only in plasma drug levels of approximately 10 mg. per cent or more. Neither drug significantly affects potassium or phosphate excretion.

5. Administered orally to gouty subjects, in $\mathbf{1 . 0}$ to $2.0-\mathrm{gm}$. daily dosage, $\mathrm{G}-25671$ is a potent uricosuric agent. In 13 such patients, free of significant renal damage, the serum urate level was reduced from a mean pre-medication figure of 9.6 mg. per cent to a mean minimum of $4.7 \mathrm{mg}$. per cent; the effect in patients with renal damage was 
less satisfactory. G-25671 also possesses antirheumatic properties sufficient to control pain and stiffness in chronic gouty arthritis but these are distinctly less pronounced than phenylbutazone and the drug is of little or no value in terminating acute gouty attacks.

6. The limiting factor in clinical use of G-25671 as a uricosuric agent in the prevention and treatment of chronic gouty arthritis is the potential hazard of toxic side reactions. Drug sensitivity (rash) developed in approximately 10 per cent of our patients. There was no indication of bone marrow depression, hepatotoxicity or neurotoxicity in this series but the observations are too few and too brief to warrant conclusions.

\section{ACKNOWLEDGMENT}

The authors wish to express their indebtedness to Geigy Pharmaceuticals, Division of Geigy Co., Inc., for the generous supply of phenylbutazone, G-25671 and other phenylbutazone derivatives.

\section{REFERENCES}

1. Brodie, B. B., Yü, T. F., Burns, J. J., Chenkin, T., Paton, B. C., Steele, J. M., and Gutman, A. B., Observations on G-25671, a phenylbutazone analogue (4-(phenylthioethyl)-1,2-diphenyl 3,5-pyrazolidinedione). Proc. Soc. Exper. Biol. \& Med., 1954, 86, 884.

2. Yü, T. F., Chenkin, T., Paton, B. C., and Randolph, V., Effect of G-25671, a phenylbutazone analogue, on urate clearance, glomerular filtration rate and renal plasma flow. J. Pharmacol. \& Exper. Therap., 1955, 113, 57.

3. Burns, J. J., Gutman, A. B., Yü, T. F., Paton, B., Perel, J., Steele, J. M., and Brodie, B. B., Isolation, identification and physiologic effects of phenylbutazone metabolites. Federation Proc., 1955, 14, 323.
4. Burns, J. J., Rose, R. K., Goodwin, S., Reichenthal, J., Horning, E. C., and Brodie, B. B., The metabolic fate of phenylbutazone (Butazolidin) in man. J. Pharmacol. \& Exper. Therap., 1955, 113, 481.

5. Goldring, W., and Chasis, H., Hypertension and $\mathrm{Hy}-$ pertensive Disease. New York, The Commonwealth Fund, 1944.

6. Sirota, J. H., Yü, T. F., and Gutman, A. B., Effect of Benemid (p-[di-n-propylsulfamyl]-benzoic acid) on urate clearance and other discrete renal functions in gouty subjects. J. Clin. Invest., 1952, 31, 692.

7. Yü, T. F., Sirota, J. H., and Gutman, A. B., Effect of phenylbutazone (3,5 dioxo-1,2-diphenyl-4-n-butylpyrazolidine) on renal clearance of urate and other discrete renal functions in gouty subjects. J. Clin. Invest., 1953, 32, 1121.

8. Burns, J. J., Rose, R. K., Chenkin, T., Goldman, A., Schulert, A., and Brodie, B. B., The physiological disposition of phenylbutazone (Butazolidin) in man and a method for its estimation in biological material. J. Pharmacol. \& Exper. Therapy., 1953, $109,346$.

9. Yü, T. F., and Gutman, A. B., Ultrafiltrability of plasma urate in man. Proc. Soc. Exper. Biol. \& Med., 1953, 84, 21.

10. Huffman, E. R., Smyth, C. J., Wilson, G. M., Jr., and Hill, R., Uricosuric effect of phenylbutazone. Ann. Rheumat. Dis., 1955, 14, 97.

11. Wyngaarden, J. B., The effect of phenylbutazone on uric acid metabolism in two normal subjects. $J$. Clin. Invest., 1955, 34, 256.

12. Gutman, A. B., Yü, T. F., and Randolph, V., Further observations on the uricosuric effects of probenecid (Benemid) in tophaceous gout. Tr. A. Am. Physicians, 1954, 67, 250.

13. Yü, T. F., and Gutman, A. B., Paradoxical retention of uric acid by uricosuric drugs in low dosage. Proc. Soc. Exper. Biol. \& Med., 1955, 90, 542.

14. Gutman, A. B., and Yü, T. F., Current principles of management in gout. Am. J. Med., 1952, 13, 744.

15. Kuzell, W. C., Schaffarzick, R. W., Naugler, W. E., Gaudin, G., Mankle, E. A., and Brown, B., Phenylbutazone (Butazolidin) in gout. Am. J. Med., 1954, 16, 212. 